\title{
Communication
}

\section{The Road towards Polyclonal Anti-SARS-CoV-2 Immunoglobulins (Hyperimmune Serum) for Passive Immunization in COVID-19}

\author{
Daniele Focosi ${ }^{1, *(\mathbb{D}}$, Marco Tuccori ${ }^{2,3}$ and Massimo Franchini ${ }^{4}$ \\ 1 North-Western Tuscany Blood Bank, Pisa University Hospital, 56124 Pisa, Italy \\ 2 Division of Pharmacology and Pharmacovigilance, University of Pisa, 56126 Pisa, Italy; \\ marco.tuccori@gmail.com \\ 3 Unit of Adverse Drug reaction Monitoring, Pisa University Hospital, 56124 Pisa, Italy \\ 4 Department of Hematology and Transfusion Medicine, Carlo Poma Hospital, 46100 Mantua, Italy; \\ massimo.franchini@asst-mantova.it \\ * Correspondence: d.focosi@ao-pisa.toscana.it
}

check for updates

Citation: Focosi, D.; Tuccori, M.; Franchini, M. The Road towards Polyclonal Anti-SARS-CoV-2 Immunoglobulins (Hyperimmune Serum) for Passive Immunization in COVID-19. Life 2021, 11, 144. https://doi.org/10.3390/life11020144

Academic Editor: Tissa Wijeratne

Received: 20 January 2021

Accepted: 11 February 2021

Published: 15 February 2021

Publisher's Note: MDPI stays neutral with regard to jurisdictional claims in published maps and institutional affiliations.

Copyright: (C) 2021 by the authors. Licensee MDPI, Basel, Switzerland. This article is an open access article distributed under the terms and conditions of the Creative Commons Attribution (CC BY) license (https:/ / creativecommons.org/licenses/by/ $4.0 /)$.

\begin{abstract}
Effective treatments specific for COVID-19 are still lacking. In the setting of passive immunotherapies based on neutralizing antibodies (nAbs), randomized controlled trials of COVID19 convalescent plasma (CCP) anti-SARS-CoV-2 Spike protein monoclonal antibodies (mAb), which have been granted emergency use authorization, have suggested benefit in early disease course (less than 72 hours from symptoms and seronegative). Meanwhile, polyclonal immunoglobulins (i.e., hyperimmune serum), derived either from CCP donations or from animals immunized with SARS-CoV-2 antigens, are likely to become the next $\mathrm{nAb}$-derived candidate. We here discuss the pros and cons of hyperimmune serum versus $\mathrm{CCP}$ and $\mathrm{mAb}$, and summarize the ongoing clinical trials of COVID-19 hyperimmune sera.
\end{abstract}

Keywords: COVID-19; SARS-CoV-2; polyclonal immunoglobulins; convalescent plasma; Cohn's fractionation; IgG; passive immunotherapy

\section{Introduction}

The ongoing COVID-19 pandemic caused by SARS-CoV-2 is totaling more than 101 million cases and 2.1 million deaths worldwide as of 1 February 2021. Many prophylactic and therapeutic regimens have been tested in randomized controlled trials (RCT), but to date, only dexamethasone (6 mg once daily) [1] and remdesivir [2] have shown clear evidence of clinical benefit. Several vaccines are likely to make an impact on the pandemic [3], but herd immunity is far from being achieved in most countries.

Many hopes rely on passive immunotherapies based on anti-Spike neutralizing antibodies (nAbs), which develop after infection in close to $90 \%$ of patients and persist for at least 5 months [4]. There have been three different exploitations of nAbs. The most immediate has been COVID-19 convalescent plasma (CCP) [5], whose efficacy seems promising in the early disease course [6] but for which many randomized controlled trials are still pending [7]. Antiviral monoclonal nAbs have also entered the market for emergency use authorization (EUA) [8]. Meanwhile, COVID-19 polyclonal IgG formulations (i.e., hyperimmune serum) are expected to be far cheaper than antiviral monoclonal nAbs (albeit with a lower mean affinity), and pharmacoeconomic benefits can make a huge difference in a pandemic setting.

Several countries have begun to direct CCP donations towards plasma manufacturers [9], to investigate CCP fractionation resulting in polyclonal IgG formulations. Polyclonal IgG can be administered intravenously (IVIg), intramuscularly or, more rarely, intranasally. IVIg manufactured from CCP should not be confused with IVIg from nonconvalescent 
donors, which have shown some benefit at high doses as an immunosuppressive treatment for COVID-19 [10-12].

An alternative source of hyperimmune serum is the immunization of animals: this has been successfully used for decades to manufacture sera used in oncohematology and transplant patients. Large mammals have historically been the preferred animals (e.g., rabbit- or horse-derived anti-thymocyte globulins [13]), but hen egg yolk containing IgY is currently a promising platform [14,15].

Hyperimmune IVIg are typically prepared from pools of 100-1000 liters of plasma, and the timely creation of dedicated CCP production chains poses difficult GMP issues within plasma vendor plants $[16,17]$. In order to be economically sustainable, contract (privately run) fractionation typically requires well over 10,000 liters of plasma per year. On the other hand, domestic (state-owned) fractionation typically requires over 100,000 200,000 liters per year in addition to starting up a fractionation facility. An "on-the-bench" mini-pool fractionation scale (MPFS) process (5-10 liters of plasma, i.e., approximately 20 recovered CCP units) using disposable devices and based on caprylic acid precipitation has been under development in Egypt since 2003, and has proven effective at purifying immunoglobulins (six-fold enrichment) [18]: such a solvent/detergent (S/D) Virus Inactivation Bag Cascade (VIPS SA, Colombier, Switzerland) is currently under investigation in NCT04383548. Another method based on the Gradiflow ${ }^{\mathrm{TM}}$ electrophoresis-based separation technology is under development [19].

In this manuscript, we systematically review the ongoing clinical trials of COVID-19 hyperimmune serum.

\section{Methods}

On 31 January 2021 we searched, online, the World Health Organization International Clinical Trial Registry Platform (ICTRP) databases (accessed at https: / www.who.int/ docs / default-source/coronaviruse/covid-19-trials.xls), NIH ClinicalTrials database (accessed at www.clinicaltrials.gov), and Cytel Global Coronavirus COVID-19 Clinical Trial Tracker (accessed at www.covid-trials.org) using the following query: "Condition = Covid19" AND "Other terms = immunoglobulin OR serum" AND "Study type = Interventional". The 565 search results were individually screened to exclude nonrelevant studies.

\section{Results}

We identified 16 clinical trials employing polyclonal immunoglobulins from convalescent donors or immunized animals. The results are summarized in Table 1.

A single trial investigated polyclonal immunoglobulins directly recovered from single donors via either immunoadsorption or double filtration plasmapheresis (DFPP), respectively: both procedures are typically therapeutic (meaning the subtracted volume is discarded rather than used for therapeutic purposes), and hence, the regulatory framework for this kind of hyperimmune serum is still to be defined. Conventional, pooled hyperimmune serum is instead under investigation in five (when sourced from immunized animals) and nine trials (when sourced from human CCP donations).

In the current regulatory framework, human hyperimmune sera are likely to enter the market faster than animal-derived sera. Among the human hyperimmune sera, two formulations are being investigated in RCTs using CCP in the control arm (NCT04381858 and NCT04395170), which represents the current gold standard for nAbs. RCTs comparing hyperimmune serum to neutralizing $\mathrm{mAbs}$ are anticipated in the near future. The typical dose is in the range of 0.1 to 0.4 grams per kilogram of recipient body weight (with a single trial using a fixed dose of $4 \mathrm{~g}$ ), with the dose repeated for 1 to 3 days. 


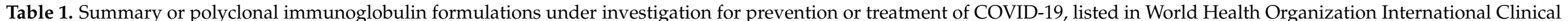

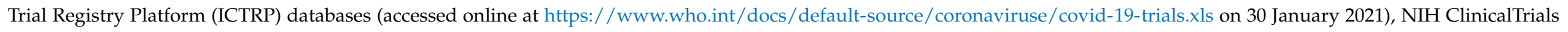

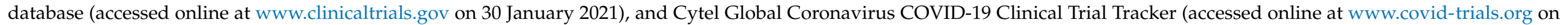
30 January 2021). BSC: best supportive care; NA: not available.

\begin{tabular}{|c|c|c|c|c|c|c|c|c|c|c|c|}
\hline Source & Recovery Method & Phase & $\begin{array}{c}\text { NCT } \\
\text { Identifier }\end{array}$ & Country & $n$ & Start Date & $\begin{array}{c}\text { Estimated } \\
\text { Completion } \\
\text { Date }\end{array}$ & Immunogen & $\begin{array}{l}\text { Formulation } \\
\text { (Brand Name) }\end{array}$ & Dosage & Indications \\
\hline \multirow{10}{*}{$\begin{array}{l}\text { Convalescent } \\
\text { humans }\end{array}$} & Immunoadsorption & $\begin{array}{l}\text { I (vs. noncon- } \\
\text { valescent } \\
\text { IVIg) }\end{array}$ & NCT04264858 & China & 10 & Mar 2020 & May 2020 & Whole virus & $\begin{array}{l}\text { Full-length } \\
\text { IgG }\end{array}$ & $\begin{array}{c}0.2 \mathrm{~g} / \mathrm{kg} / \text { day for } \\
3 \text { days }\end{array}$ & $\begin{array}{l}\text { Treatment of severe } \\
\text { COVID-19 }\end{array}$ \\
\hline & $\begin{array}{l}\text { Double filtration } \\
\text { plasmapheresis } \\
\text { (DFPP) }\end{array}$ & I & NCT04418531 & Italy & 10 & Jun 2020 & Sep 2020 & Whole virus & $\begin{array}{l}\text { Full-length } \\
\text { IgG }\end{array}$ & n.a. & $\begin{array}{l}\text { Treatment of moderate } \\
\text { COVID-19 }\end{array}$ \\
\hline & \multirow{8}{*}{ Plasma fractionation } & III & NCT04546581 & USA & 500 & Oct 2020 & Jul 2021 & Whole virus & $\begin{array}{c}\text { Full-length } \\
\text { IgG (H-Ig; } \\
\text { CoVIg-19 } \\
\text { Plasma } \\
\text { Alliance) }\end{array}$ & n.a., single infusion & $\begin{array}{l}\text { Treatment of moderate } \\
\text { COVID-19 [20] }\end{array}$ \\
\hline & & I & NCT04548557 & Pakistan & 60 & Sep 2020 & Nov 2020 & Whole virus & $\begin{array}{l}\text { Full-length } \\
\text { IgG }\end{array}$ & $\begin{array}{l}4 \text { dose-finding arms } \\
\text { of } 0.15 \text { to } 0.3 \mathrm{~g} / \mathrm{kg}\end{array}$ & $\begin{array}{l}\text { Treatment of severe } \\
\text { and critically ill } \\
\text { COVID-19 }\end{array}$ \\
\hline & & II & NCT04383548 & Egypt & 100 & Jun 2020 & Jan 2021 & Whole virus & $\begin{array}{l}\text { Full-length } \\
\text { IgG }\end{array}$ & $\begin{array}{c}\text { Prophylaxis in } \\
\text { younger than } 20 \\
\text { years }\end{array}$ & $\begin{array}{c}\text { Post-exposure } \\
\text { prevention (group A) } \\
\text { and treatment of } \\
\text { moderate COVID-19 } \\
\text { (group B) }\end{array}$ \\
\hline & & I/II (vs. BSC) & NCT04521309 & Pakistan & 50 & Jun 2020 & Mar 2021 & Whole virus & $\begin{array}{l}\text { Full-length } \\
\text { IgG }\end{array}$ & $\begin{array}{l}4 \text { dose-finding arms } \\
\text { of } 0.2 \text { to } 0.35 \mathrm{~g} / \mathrm{kg}\end{array}$ & $\begin{array}{l}\text { Treatment of severe } \\
\text { and critically ill [21] }\end{array}$ \\
\hline & & II (vs. BSC) & NCT04555148 & $\begin{array}{l}\text { South } \\
\text { Korea }\end{array}$ & 60 & Sep 20 & Aug 2021 & Whole virus & $\begin{array}{l}\text { Full-length } \\
\text { IgG (GC5131) }\end{array}$ & 3 dose-finding arms & $\begin{array}{c}\text { Treatment of moderate } \\
\text { COVID-19 }\end{array}$ \\
\hline & & $\mathrm{I} / \mathrm{II}$ & NCT04550325 & Israel & 12 & Aug 2020 & Nov 2020 & Whole virus & $\begin{array}{l}\text { Full-length } \\
\text { IgG }\end{array}$ & $4 \mathrm{~g}$ & $\begin{array}{l}\text { Treatment of mild } \\
\text { COVID-19 [22] }\end{array}$ \\
\hline & & \multirow[t]{2}{*}{ III (vs. CCP) } & NCT04381858 & Mexico & 500 & May 2020 & Nov 2020 & Whole virus & $\begin{array}{l}\text { Full-length } \\
\text { IgG }\end{array}$ & $\begin{array}{l}0.3 \mathrm{gr} / \mathrm{kg} / \text { day } \\
(5 \mathrm{doses}) \mathrm{vs} . \\
\text { CCP > 1:640 }\end{array}$ & $\begin{array}{l}\text { Treatment of severe } \\
\text { COVID-19 }\end{array}$ \\
\hline & & & NCT04395170 & Colombia & 75 & Sep 2020 & Jun 2021 & Whole virus & $\begin{array}{l}\text { Full-length } \\
\text { IgG (Life } \\
\text { Factor Zona } \\
\text { Franca S.a.s.) }\end{array}$ & $\begin{array}{l}0.1 \mathrm{~g} / \mathrm{kg}(\max 50 \mathrm{~g}) \\
\text { on days } 1 \text { and } 3\end{array}$ & $\begin{array}{c}\text { Treatment of moderate } \\
\text { COVID-19 }\end{array}$ \\
\hline
\end{tabular}


Table 1. Cont

\begin{tabular}{|c|c|c|c|c|c|c|c|c|c|c|c|}
\hline Source & Recovery Method & Phase & $\begin{array}{c}\text { NCT } \\
\text { Identifier }\end{array}$ & Country & $n$ & Start Date & $\begin{array}{l}\text { Estimated } \\
\text { Completion } \\
\text { Date }\end{array}$ & Immunogen & $\begin{array}{l}\text { Formulation } \\
\text { (Brand Name) }\end{array}$ & Dosage & Indications \\
\hline Bovine & & $\begin{array}{c}\mathrm{Ib}(\mathrm{vs} . \\
\text { placebo) }\end{array}$ & NCT04469179 & USA & 21 & Sep 2020 & Dec 2020 & $\begin{array}{l}\text { Anti-wild- } \\
\text { type and } \\
\text { recombinant } S \\
\text { from insect } \\
\text { cells }\end{array}$ & $\begin{array}{c}\text { Full-length } \\
\text { IgG (SAB-185) }\end{array}$ & $\begin{array}{l}3 \text { dose-finding arms } \\
\text { of } 10 \text { to } 50 \mathrm{mg} / \mathrm{kg}\end{array}$ & $\begin{array}{c}\text { Treatment of } \\
\text { COVID-19 outpatients }\end{array}$ \\
\hline \multirow{4}{*}{ Equine } & & $\mathrm{I} / \mathrm{II}$ & NCT04573855 & Brazil & 41 & Dec 2020 & Mar 2021 & n.a. & $\mathrm{F}\left(\mathrm{ab}^{\prime}\right)_{2}$ & n.a. & $\begin{array}{l}\text { Treatment of moderate } \\
\text { COVID-19 [23] }\end{array}$ \\
\hline & & II & NCT04610502 & Costa Rica & 26 & Sep 2020 & Dec 2020 & $\begin{array}{c}\text { Anti-Santi- } \\
\text { S1,N,S1+E+M }\end{array}$ & $\begin{array}{l}\text { Full-length } \\
\text { IgG }\end{array}$ & $110 \mathrm{~mL}$ vial on day 1 & $\begin{array}{c}\text { Treatment of moderate } \\
\text { and severe COVID-19 } \\
\text { [24] }\end{array}$ \\
\hline & & $\mathrm{II} / \mathrm{III}$ & NCT04494984 & Argentina & 242 & Jul 2020 & Dec 2020 & RBD & $\begin{array}{c}\mathrm{F}\left(\mathrm{ab}^{\prime}\right)_{2} \\
\text { (INM05; } \\
\text { Inmunova s.a.) }\end{array}$ & $\begin{array}{c}4 \mathrm{mg} / \mathrm{kg} \text { on days } 1 \\
\text { and 3; mean PRNT } \\
1: 10,240 .\end{array}$ & $\begin{array}{l}\text { Treatment of early, } \\
\text { moderate to severe } \\
\text { COVID-19 [25] }\end{array}$ \\
\hline & & $\begin{array}{l}\text { I/II (vs. } \\
\text { placebo) }\end{array}$ & NCT04514302 & Mexico & 51 & Oct 2020 & Jun 2021 & n.a. & $\begin{array}{c}\mathrm{F}\left(\mathrm{ab}^{\prime}\right) 2 \\
\text { (INOSARS) }\end{array}$ & $\begin{array}{l}2 \text { dose-finding arms } \\
(2 \text { vials and } 6 \text { vials })\end{array}$ & $\begin{array}{l}\text { Treatment of moderate } \\
\text { COVID-19 }\end{array}$ \\
\hline Hen & & I (vs. placebo) & NCT04567810 & Australia & 48 & Sep 2020 & Dec 2020 & n.a. & $\operatorname{Ig} Y$ & $\begin{array}{c}6 \text { dose-finding arms } \\
\text { (2 to } 24 \mathrm{mg} \text { total } \\
\text { dose) }\end{array}$ & Healthy subjects [15] \\
\hline
\end{tabular}


The typical exclusion criteria for hyperimmune serum trials include patients with prior receipt of standard IVIg (not hyperimmune to SARS-CoV-2) within 45 days; a history of allergy to IVIg or plasma products; a history of selective IgA deficiency ( $<7 \mathrm{mg} / \mathrm{dL}$ ) with a documented presence of anti-IgA antibodies; any medical conditions for which receipt of the required volume of intravenous fluid may be dangerous to the patient (including New York Association Class III or IV stage heart failure); and any of the following thrombotic or procoagulant disorders: acute coronary syndromes, cerebrovascular syndromes and pulmonary or deep venous thrombosis within 28 days of randomization, a history of the prothrombin gene mutation 20210, homozygous Factor V Leiden mutations, antithrombin III deficiency, protein C deficiency, protein S deficiency or antiphospholipid syndrome.

\section{Discussion}

Antiviral hyperimmune sera are already marketed for the post-exposure prophylaxis of hepatitis B (hepatitis B immune globulin (HBIG), targeting hepatitis B surface antigen-HbsAg) [26], rabies virus [27] and, more interestingly, for another respiratory pathogen, respiratory syncytial virus (RSV) [28,29]. Post-exposure prophylaxis (especially of healthcare workers), as well as the early treatment of cases, will likely remain the main indications for COVID-19 hyperimmune serum.

Plasma fractionation results in IgG purification, hence removing undesirable plasma components (e.g., prothrombotic factors) but also potentially depleting beneficial ingredients (e.g., several IgG subclasses, IgA, antithrombin III, etc.). Additionally, most of the anti-SARS-CoV-2 neutralizing antibody responses in the IgG class have been shown to be associated with the $\operatorname{IgG}_{1}$ and $\operatorname{IgG}_{3}$ subclasses [30]: unfortunately, the $\operatorname{IgG}_{3}$ fraction is often depleted during industrial fractionation [31], and its impact on neutralizing titers should be carefully evaluated.

COVID-19 hyperimmune serum is considered a virally safe product since SARS-CoV-2 is inactivated by S/D treatment [32] and nonenveloped viral contaminants are additionally removed by nanofiltration. Fatty acids are also a good option for pathogen inactivation: in 2002, it was reported that caprylic acid [33] and octanoic acid [34] were as effective as S/D treatment at inactivating enveloped viruses.

In April 2020, the main plasma manufacturers (Takeda, Grifols [20], Biotest, CSL Behring, LFB, Octapharma, ADMA Biologics, BioPharma Plasma, GC Pharma, BPL, Sanquin, Liminal BioSciences, NBI, and Silanes) joined, instead, under The CoVIg19 Plasma Alliance (https: / /www.covig-19plasmaalliance.org/ (accessed on 11 February 2021)). The Bill \& Melinda Gates Foundation is providing advisory support. Microsoft is providing technology including the Alliance website and the Plasma Bot, a self-screening tool that anyone can use to see if they qualify to donate their plasma. In October 2020, Takeda, which initially led the Alliance, withdrew the phase 1b RCT of its TAK-671 hyperimmune serum formulation (NCT04464460) as a business decision, focusing instead on the shared NCT04546581.

On the other side of the coin, lone players include Aegros Covimmune ${ }^{\mathrm{TM}}$ (https: / / aegros.com.au/ (accessed on 11 February 2021)), Lifefactors Zona Franca S.A.S. (https: / / lifefactors.com.co/ (accessed on 11 February 2021)), and the joint venture between the Italian Kedrion Biopharma S.p.a. and the Israeli Kamada Ltd, in collaboration with the Irving Medical Center of Columbia University [22].

Animal-derived hyperimmune serum is also worthy of investigation because it can be easily scaled up. Preliminary reports showed that the receptor binding domain (RBD) from the viral Spike glycoprotein elicits high titers of $\mathrm{nAb}$ in horses $[23,35]$ and glycoengineered swine [36], and several companies embarked on clinical trials. Manufacturing animal sera often relies on different and/or additional steps when compared to human serum: for example, in order to avoid xenogeneic immunizations and serum sickness, plasma can be digested with pepsin under controlled conditions, rendering $F\left(a b^{\prime}\right) 2$ fragments from the immunoglobulin molecules. The fragments are then further purified by salting out and 
membrane $\mathrm{Q}$ chromatography. The bulk solution is typically nanofiltered $(20 \mathrm{~nm})$ and then sterilized through a $0.2 \mu \mathrm{m}$-pore cartridge.

Since plasma-derived drugs could theoretically suffer from many problems, including low potency, impurities (including infectious viruses [37] and clotting factors [38]), constraints on supply, the antibody-dependent enhancement (ADE) of infection, and batchto-batch variation [39], polyvalent, $10^{3}$ - to $10^{4}$-diverse recombinant hyperimmune antibody drugs generated from convalescent human blood donors, vaccinated human blood donors, and humanized animal repertoires will likely be an additional field of research for the coming years [40].

\section{Conclusions}

While the efficacy of COVID-19 hyperimmune serum remains hard to guess against a respiratory pathogen and in a landscape with quickly evolving viral strains, hyperimmune serum has several advantages over CCP (e.g., a smaller reinfusion volume, an easier administration route and easier preservation) and $\mathrm{mAbs}$ (more diversified nAbs against emerging variants of concern, and far cheaper), summarized in Table 2, making it a product worth being fully investigated in clinical trials. A few studies will be completed soon, and the results will drive the design of the next round of trials.

Table 2. A comparison of neutralizing antibody (nAb)-based therapies for COVID-19.

\begin{tabular}{|c|c|c|c|}
\hline & CCP & $\begin{array}{c}\text { Hyperimmune } \\
\text { Serum (Polyclonal } \\
\text { IgG) }\end{array}$ & $\begin{array}{l}\text { Monoclonal } \\
\text { Antibodies }\end{array}$ \\
\hline Speed of access & $\begin{array}{c}\text { Weeks (as soon as } \\
\text { convalescents appear) }\end{array}$ & $>1$ year & $>1$ year \\
\hline Safety issues & $\begin{array}{c}\text { Safe (pathogen } \\
\text { inactivation, possible } \\
\text { plasma protein } \\
\text { allergies) }\end{array}$ & $\begin{array}{c}\text { Safe } \\
\text { (solvent/detergent, } \\
\text { but } \\
\text { ABO-incompatible) }\end{array}$ & $\begin{array}{l}\text { Extremely safe } \\
\text { (recombinant } \\
\text { technology) }\end{array}$ \\
\hline Potency & $\begin{array}{c}\text { Very high } \\
\text { (high PRNT titer; } \\
\text { includes neutralizing } \\
\text { IgA and IgM, and } \\
\text { factors other than } \\
\text { antibodies) }\end{array}$ & $\begin{array}{c}\text { High (no IgA; less } \\
\left.\operatorname{IgG}_{3}\right)\end{array}$ & $\begin{array}{l}\text { High (nanomolar } \\
\text { IC } 50 \text { ) } \\
\text { Very high for } \mathrm{Ab} \\
\text { cocktails }\end{array}$ \\
\hline Cost & $€$ & $€ €$ & $€ € € €$ \\
\hline Logistics & $\begin{array}{c}+2-+8^{\circ} \mathrm{C} \text { (if fresh) or } \\
<-25^{\circ} \mathrm{C} \text { (if frozen); } \\
\text { i.v. }\end{array}$ & $+2-+8^{\circ}$ C; s.c. $/$ i.v. & $+2-+8^{\circ} \mathrm{C}$; s.c. $/$ i.v. \\
\hline Scalability & Not easily scalable & Easily scalable & Very easily scalable \\
\hline
\end{tabular}

Author Contributions: D.F. designed the paper, performed the data mining and wrote the first draft; M.F. and M.T. analyzed the data and critically revised the final version. All authors have read and agreed to the published version of the manuscript.

Funding: This review was not supported by any funding.

Institutional Review Board Statement: Not applicable.

Informed Consent Statement: Not applicable.

Data Availability Statement: Please refer to suggested Data Availability Statements in section “MDPI Research Data Policies" at https:/ / www.mdpi.com/ethics (accessed on 11 February 2021).

Conflicts of Interest: The authors have no conflicts of interest to declare. 


\section{References}

1. T.R.C. Group. Dexamethasone in Hospitalized Patients with Covid-19_Preliminary Report. N. Engl. J. Med. 2020. [CrossRef]

2. Beigel, J.H.; Tomashek, K.M.; Dodd, L.E.; Mehta, A.K.; Zingman, B.S.; Kalil, A.C.; Hohmann, E.; Chu, H.Y.; Luetkemeyer, A.; Kline, S.; et al. Remdesivir for the Treatment of Covid-19-Final Report. N. Engl. J. Med. 2020, 383, 1813-1826. [CrossRef]

3. Rawat, K.; Kumari, P.; Saha, L. COVID-19 vaccine: A recent update in pipeline vaccines, their design and development strategies. Eur. J. Pharmacol. 2021, 892, 173751. [CrossRef]

4. Wajnberg, A.; Amanat, F.; Firpo, A.; Altman, D.R.; Bailey, M.J.; Mansour, M.; McMahon, M.; Meade, P.; Mendu, D.R.; Muellers, K.; et al. Robust neutralizing antibodies to SARS-CoV-2 infection persist for months. Science 2020, 370, 1227-1230. [CrossRef]

5. Focosi, D.; Anderson, A.O.; Tang, J.W.; Tuccori, M. Convalescent Plasma Therapy for COVID-19: State of the Art. Clin. Microbiol. Rev. 2020, 33, e00072-00020. [CrossRef] [PubMed]

6. $\quad$ Klassen, S.A.; Senefeld, J.W.; Johnson, P.W.; Carter, R.E.; Wiggins, C.C.; Shoham, S.; Grossman, B.J.; Henderson, J.P.; Musser, J.; Salazar, E.; et al. Evidence favoring the efficacy of convalescent plasma for COVID-19 therapy. Medrxiv Prepr. Serv. Health Sci. 2020. [CrossRef]

7. Focosi, D.; Farrugia, A. The art of the possible in approaching efficacy trials for COVID19 convalescent plasma. Int. J. Infect. Dis. Ijid Off. Publ. Int. Soc. Infect. Dis. 2021, 102, 244-246.

8. Tuccori, M.; Ferraro, S.; Convertino, I.; Cappello, E.; Valdiserra, G.; Blandizzi, C.; Maggi, F.; Focosi, D. Anti-SARS-CoV-2 neutralizing monoclonal antibodies: Clinical pipeline. $m A$ bs 2020, 12, 1854149. [CrossRef] [PubMed]

9. Focosi, D.; Tuccori, M.; Antonelli, G.; Maggi, F. What is the optimal usage of Covid-19 convalescent plasma donations? Clin. Microb. Infect 2020, S1198-743X, 30589-30589. [CrossRef]

10. Díez, J.-M.; Romero, C.; Gajardo, R. Currently available intravenous immunoglobulin contains antibodies reacting against SARS-CoV-2 antigens. Immunotherapy 2020, 12, 571-576.

11. Cao, W.; Liu, X.; Bai, T.; Fan, H.; Hong, K.; Song, H.; Han, Y.; Lin, L.; Ruan, L.; Li, T. High-Dose Intravenous Immunoglobulin as a Therapeutic Option for Deteriorating Patients With Coronavirus Disease 2019. Open Forum Infect. Dis. 2020, 7, 102. [CrossRef] [PubMed]

12. Hung, I.F.N.; To, K.K.W.; Lee, C.K.; Lee, K.L.; Yan, W.W.; Chan, K.; Chan, W.M.; Ngai, C.W.; Law, K.I.; Chow, F.L.; et al. Hyperimmune IV immunoglobulin treatment: A multicenter double-blind randomized controlled trial for patients with severe 2009 influenza A(H1N1) infection. Chest 2013, 144, 464-473. [CrossRef] [PubMed]

13. Siddiqui, S.; Cox, J.; Herzig, R.; Palaniyandi, S.; Hildebrandt, G.C.; Munker, R. Anti-thymocyte globulin in haematology: Recent developments. Indian J. Med Res. 2019, 150, 221-227. [PubMed]

14. Pereira, E.P.V.; van Tilburg, M.F.; Florean, E.O.P.T.; Guedes, M.I.F. Egg yolk antibodies (IgY) and their applications in human and veterinary health: A review. Int Immunopharmacol. 2019, 73, 293-303. [CrossRef]

15. de la Lastra, J.M.P.; Baca-González, V.; Asensio-Calavia, P.; González-Acosta, S.; Morales-delaNuez, A. Can Immunization of Hens Provide Oral-Based Therapeutics against COVID-19? Vaccines 2020, 8, 486. [CrossRef] [PubMed]

16. Radosevich, M.; Burnouf, T. Intravenous immunoglobulin G: Trends in production methods, quality control and quality assurance Vox Sang. 2010, 98, 12-28. Vox Sang. 2010, 98, 12-28. [CrossRef]

17. WHO. Annex 4. Recommendations for the collection, quality control and regulation of human plasma for fractionation. WHO Tech. Rep. Ser. 2007, 941, 189-264.

18. El-Ekiaby, M.; Vargas, M.; Sayed, M.; Gorgy, G.; Goubran, H.; Radosevic, M.; Burnouf, T. Minipool caprylic acid fractionation of plasma using disposable equipment: A practical method to enhance immunoglobulin supply in developing countries. PLoS Negl. Trop. Dis. 2015, 9, e0003501. [CrossRef]

19. Li, G.; Stewart, R.; Conlan, B.; Gilbert, A.; Roeth, P.; Nair, H. Purification of human immunoglobulin G: A new approach to plasma fractionation. Vox Sang. 2002, 83, 332-338. [CrossRef] [PubMed]

20. Hwang, S.; Song, G.W.; Chung, Y.K.; Ahn, C.S.; Kim, K.H.; Moon, D.B.; Ha, T.Y.; Jung, D.H.; Park, G.C.; Yoon, Y.I.; et al Determination of Hepatitis B Immunoglobulin Infusion Interval Using Pharmacokinetic Half-life Simulation for Posttransplant Hepatitis B Prophylaxis. J. Korean Med. Sci. 2019, 34, e251. [CrossRef] [PubMed]

21. Bock, H.L.; Milcke-Ungeheuer, L. Active and passive rabies immunization: The effect of administering hyperimmune globulin before the vaccine. J. Biol. Stand. 1988, 16, 67-69. [CrossRef]

22. Sanders, S.L.; Agwan, S.; Hassan, M.; van Driel, M.L.; del Mar, C.B. Immunoglobulin treatment for hospitalised infants and young children with respiratory syncytial virus infection. Cochrane Database Syst. Rev. 2019, 8, Cd009417. [CrossRef]

23. Wasserman, R.L.; Greener, B.N.; Mond, J. RI-002, an intravenous immunoglobulin containing high titer neutralizing antibody to RSV and other respiratory viruses for use in primary immunodeficiency disease and other immune compromised populations. Expert Rev. Clin. Immunol. 2017, 13, 1107-1119. [CrossRef] [PubMed]

24. Suthar, M.S.; Zimmerman, M.; Kauffman, R.; Mantus, G.; Linderman, S.; Vanderheiden, A.; Nyhoff, L.; Davis, C.; Adekunle, S.; Affer, M.; et al. Rapid generation of neutralizing antibody responses in COVID-19 patients. Cell Rep. Med. 2020, 1, 100040. [CrossRef] [PubMed]

25. Audet, S.; Virata-Theimer, M.L.; Beeler, J.A.; Scott, D.E.; Frazier, D.J.; Mikolajczyk, M.G.; Eller, N.; Chen, F.M.; Yu, M.Y. Measlesvirus-neutralizing antibodies in intravenous immunoglobulins. J. Infect Dis. 2006, 194, 781-789. [CrossRef] [PubMed]

26. Rabenau, H.F.; Biesert, L.; Schmidt, T.; Bauer, G.; Cinatl, J.; Doerr, H.W. SARS-coronavirus (SARS-CoV) and the safety of a solvent/detergent (S/D) treated immunoglobulin preparation. Biologicals 2005, 33, 95-99. [CrossRef] [PubMed] 
27. Korneyeva, M.; Hotta, J.; Lebing, W.; Rosenthal, R.S.; Franks, L.; Petteway, S.R. Enveloped Virus Inactivation by Caprylate: A Robust Alternative to Solvent-Detergent Treatment in Plasma Derived Intermediates. Biologicals 2002, 30, 153-162. [CrossRef]

28. Dichtelmüller, H.; Rudnick, D.; Kloft, M. Inactivation of Lipid Enveloped Viruses by Octanoic Acid Treatment of Immunoglobulin Solution. Biologicals 2002, 30, 135-142. [CrossRef] [PubMed]

29. Vandeberg, P.; Cruz, M.; Diez, J.M.; Merritt, W.K.; Santos, B.; Trukawinski, S.; Wellhouse, A.; José, M.; Willis, T. Production of anti-SARS-CoV-2 hyperimmune globulin from convalescent plasma. biorXiv 2020. [CrossRef]

30. ContractPharma. Kamada Signs Supply Agreement with Israeli Health Authorities. 2020. Available online: https: / / www.contractpharma.com/contents /view_breaking-news/2020-10-22/kamada-signs-supply-agreement-with-israelihealth-authorities / (accessed on 5 November 2020).

31. Pan, X.; Zhou, P.; Fan, T.; Wu, Y.; Zhang, J.; Shi, X.; Shang, W.; Fang, L.; Jiang, X.; Shi, J.; et al. Immunoglobulin fragment F(ab')2 against RBD potently neutralizes SARS-CoV-2 in vitro. Antivriral Res. 2020, 182, 104868. [CrossRef]

32. Cunha, L.E.R.; Stolet, A.A.; Strauch, M.A.; Pereira, V.A.R.; Dumard, C.H.; Gomes, A.M.O.; Souza, P.N.C.; Fonseca, J.G.; Pontes, F.E.; Meirelles, L.G.R.; et al. Potent neutralizing equine antibodies raised against recombinant SARS-CoV-2 spike protein for COVID-19 passive immunization therapy. medrXiv 2020. [CrossRef]

33. Vanhove, B.; Duvaux, O.; Rousse, J.; Royer, P.-J.; Evanno, G.; Ciron, C.; Lheriteau, E.; Vacher, L.; Gervois, N.; Oger, R.; et al. High neutralizing potency of swine glyco-humanized polyclonal antibodies against SARS-CoV-2. medrXiv 2020. [CrossRef]

34. Bjøro, K.; Frøland, S.S.; Yun, Z.; Samdal, H.H.; Haaland, T. Hepatitis C infection in patients with primary hypogammaglobulinemia after treatment with contaminated immune globulin. N. Engl. J. Med. 1994, 331, 1607-1611. [CrossRef] [PubMed]

35. Etscheid, M.; Breitner-Ruddock, S.; Gross, S.; Hunfeld, A.; Seitz, R.; Dodt, J. Identification of kallikrein and FXIa as impurities in therapeutic immunoglobulins: Implications for the safety and control of intravenous blood products. Vox Sang. 2012, 102, 40-46. [CrossRef]

36. Lejtenyi, D.; Mazer, B. Consistency of protective antibody levels across lots of intravenous immunoglobulin preparations. $J$. Allergy Clin. Immunol. 2008, 121, 254-255. [CrossRef] [PubMed]

37. Keating, S.M.; Mizrahi, R.A.; Adams, M.S.; Asensio, M.A.; Benzie, E.; Carter, K.P.; Chiang, Y.; Edgar, R.C.; Gautam, B.K.; Gras, A.; et al. Capturing and Recreating Diverse Antibody Repertoires as Multivalent Recombinant Polyclonal Antibody Drugs. bioRxiv 2020. [CrossRef]

38. Ali, S.; Luxmi, S.; Anjum, F.; Muhaymin, S.M.; Uddin, S.M.; Ali, A.; Ali, M.R.; Tauheed, S.; Khan, M.; Bajwa, M.; et al. Hyperimmune anti-COVID-19 IVIG (C-IVIG) Therapy for Passive Immunization of Severe and Critically Ill COVID-19 Patients: A structured summary of a study protocol for a randomised controlled trial. Trials 2020, 21, 905. [CrossRef]

39. León, G.; Herrera, M.; Vargas, M.; Arguedas, M.; Sánchez, A.; Segura, Á.; Gómez, A.; Solano, G.; Corrales-Aguilar, E.; Risner, K.; et al. Development and pre-clinical characterization of two therapeutic equine formulations towards SARS-CoV-2 proteins for the potential treatment of COVID-19. medrXiv 2020. [CrossRef]

40. Zylberman, V.; Sanguineti, S.; Pontoriero, A.V.; Higa, S.V.; Cerutti, M.L.; Seijo, S.M.M.; Pardo, R.; Muñoz, L.; Intrieri, M.E.A.; Alzogaray, V.A.; et al. Development of a hyperimmune equine serum therapy for COVID-19 in Argentina. Medicina 2020, 80 (Suppl. 3), 1-6. 